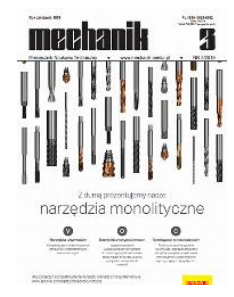

How to cite this article:

Authors: Kazimierz Czechowski, Daniel Toboła, Iwona Wronska

Title of article: „Nanostructured multilayer coatings on cemented carbide and high speed steel cutting tools”

Mechanik, No. 3 (2019)

DOI: https://doi.org/10.17814/mechanik.2019.3.26

\title{
Nanostructured multilayer coatings on cemented carbide and high speed steel cutting tools
}

\author{
KAZIMIERZ CZECHOWSKI \\ DANIEL TOBOŁA \\ IWONA WRONSKA*
}

\begin{abstract}
Dr inż. Kazimierz Czechowski, kazimierz.czechowski@ios.krakow.pl, https://orcid.org/0000-0001-6554-5106 - Instytut Zaawansowanych Technologii Wytwarzania (The Institute of Advanced Manufacturing Technology), Kraków, Polska; from april 1 2020: kazimierz.czechowski@kit.lukasiewicz.gov.pl - Sieć Badawcza Łukasiewicz - Krakowski Instytut Technologiczny (Łukasiewicz Research Network - Krakow Institute of Technology) Dr inż. Daniel Toboła, daniel.tobola@ios.krakow.pl, https://orcid.org/0000-0001-7966-240X - Instytut Zaawansowanych Technologii Wytwarzania (The Institute of Advanced Manufacturing Technology), Kraków, Polska; from april 12020 : daniel.tobola@kit.lukasiewicz.gov.pl - Sieć Badawcza Łukasiewicz - Krakowski Instytut Technologiczny (Łukasiewicz Research Network Krakow Institute of Technology)

Mgr inż. Iwona Wronska, iwona.wronska@ios.krakow.pl, https://orcid.org/0000-0003-2737-5497 - Instytut Zaawansowanych Technologii Wytwarzania (The Institute of Advanced Manufacturing Technology), Kraków, Polska
\end{abstract}

The state of the art of deposition of wear resistant coatings on cemented carbide and high speed steel cutting tools is presented with special regard to new possibilities in this field. On the basis of some results of research, at the Institute of Advanced Manufacturing Technology, carried out on the development of PVD arc multilayer nanostructured and superlattice coatings, it was shown that these coatings can contribute to the increase in tool lives.

KEYWORDS: coatings, arc plasma PVD method, tools, tool life, carbide, high speed steel

\section{Introduction}

Coating of tool working parts is now a very important and dynamically developing field of surface engineering. Coatings on working parts of tools in industrial practice are usually applied by CVD and PVD methods. The older method is CVD (chemical vapor deposition), which involves a chemical reaction of gaseous components of the atmosphere, leading to the formation of a thin hard layer on the surface of a tool. Traditionally, this process takes place at a temperature of $900-1100^{\circ} \mathrm{C}$, which limits its use. Therefore work was carried out to reduce the temperature of the coating deposition process to below $600^{\circ} \mathrm{C}$, including electrical activation of gaseous reagents (PACVD/PECVD - plasma assisted/plasma enhanced CVD). The PVD (physical vapor deposition) method, on the other hand, involves the application of thin layers by their physical vapor deposition. The process takes place at a significantly reduced pressure (of the order of 0.1-1 $\mathrm{Pa}$ ) and at temperatures of $300-700^{\circ} \mathrm{C}$. Variations of the PVD method differ in simpler solutions by the method of heat input (e.g. by resistance, induction and laser heating or electron beam bombardment) needed for evaporation of the deposited material, and in more complex cases - by the way of obtaining the ionized gas phase, the so-called plasma. In PVD methods, plasma can be obtained, inter alia, by thermal evaporation (ion plating method), evaporation of the metal and ionization of its vapors through a cathodic arc at the place of their formation (arc deposition method), pushing the particles of deposited material from the cathode as a result of high energy ion bombardment (ion spraying method - sputter deposition, e.g. as a result of forming a suitably shaped magnetic field in the magnetron method - magnetron sputtering). In modern coating application devices, various configurations of PVD methods are used [1-5].

The PVD arc method is used at the Institute of Advanced Manufacturing Technology. Plasma is created as a result of metal evaporation and ionization of its vapors by a cathode arc at the site of their formation, therefore it has a high degree of ionization (approximately 90\%). The anode is the walls of the vacuum chamber. The orientation and increase of the kinetic energy of ions occurs by polarization with negative 
voltage of the substrate, on which the coating is applied. High-energy ions produced in the arc-cathode process produce higher density coatings at a relatively lower application temperature compared to other PVD processes $[4,5]$.

Coatings applied to cutting tools can consist of nitrides, carbides, carbonitrides and oxides and have a singlelayer (monolithic, composite, gradient) or multilayer structure (in the form of microlayers, nanolayers, superlattices). The multilayer coating ensures a more favorable stress distribution and better resistance to cracking, because the crack energy is dissipated by its deflection and branching [1-5].

In multilayer coatings, it is possible to deposit - on a micro scale - functional layers. Examples of such functional layers may be: metallic adhesive layer (e.g. Ti, $\mathrm{Cr}$, Mo) with a thickness of 0.1-0.3 $\mu \mathrm{m}$ (applied to the substrate), basic layer with high hardness and possibly low stress levels (e.g. TiN, CrN, ZrN, TiCN) 1-2 $\mu \mathrm{m}$ thick, heat blocking layer (e.g. TiAlN, TiZrN) $-2 \mu \mathrm{m}$ thick, low friction layer (e.g. Cr, TiN, CrN, TiCrN) 0.5-1 $\mu \mathrm{m}$ thick (as the last of applied layers) [6]. Configurations of the layers applied to the adhesive layer depend on the intended use of the coating. In turn, the multilayer coating on the nanoscale provides tools with, among others: an optimal ratio of hardness to internal stresses (decisive for high stability of the tool geometry and their even wear), higher thermal and chemical resistance (enabling dry machining at higher cutting speeds and guaranteeing less groove wear), better sliding properties (resulting in better chip formation and higher surface quality), higher wear resistance (and thus lower tool costs) [7].

Analysis of the requirements for the functional properties of coatings, especially those used for cutting edges of tools working in difficult conditions (e.g. dry high speed machining), showed that the hardness of the coating and its thermal stability (due to the high temperature of cutting edges of tools during cutting) are very important. Variation of the stable resistance of the coatings is shown in fig. 1. As can be seen, the TiCN coating, which reaches the highest hardness immediately after application, quickly loses it with increasing temperature (especially after reaching $700^{\circ} \mathrm{C}$ ), while hardness of the other coatings decreases rapidly at a much higher temperature. Nitride coating based on the AlCr alloy shows extremely high thermal resistance [8].

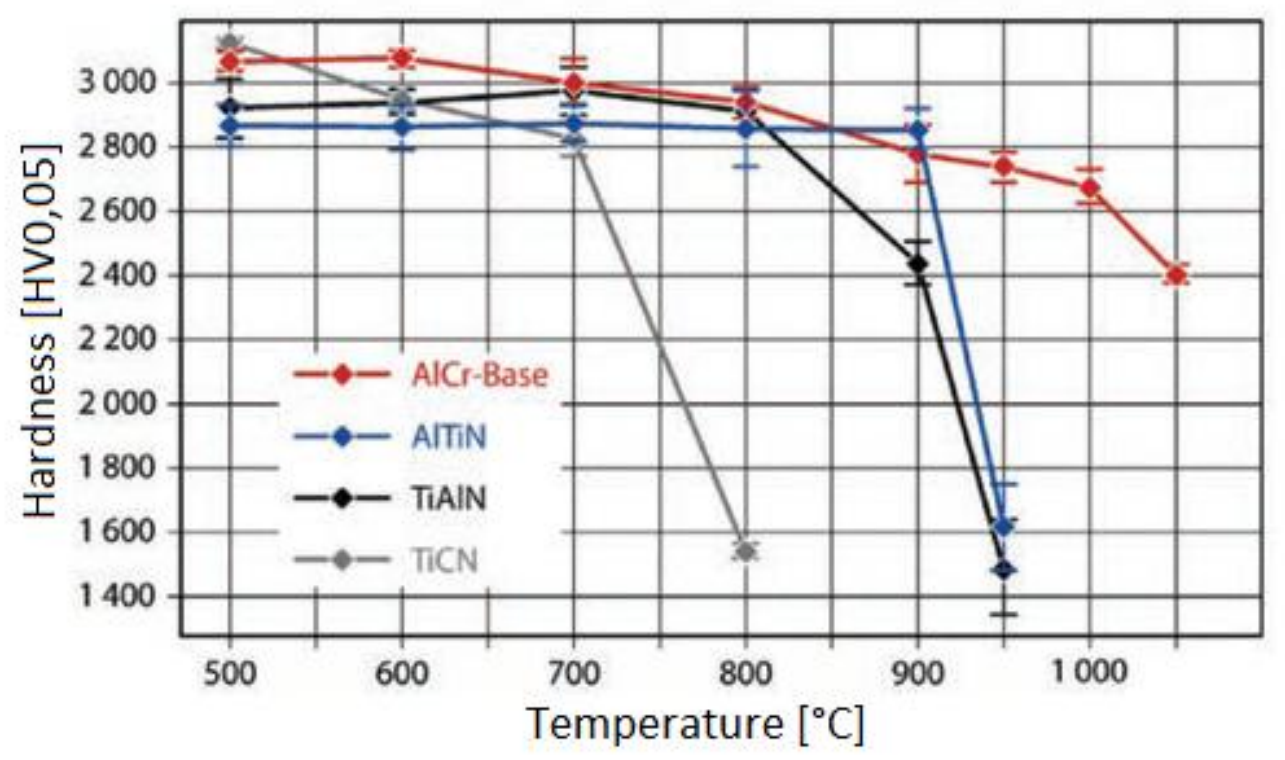

Fig. 1. Effect of temperature on hardness of various types of coatings deposited by PVD methods [8]

\section{Examples of modern coatings deposited by PVD methods}

Modern coatings for cutting tools blades are offered in the world by many companies (including Oerlikon Balzers, Ionbond, Platit, CemeCon, Hauzer Techno Coating, SHM), and many research centers are working on improving coatings, often for specific applications. Coatings deposited by PVD methods are more and more often multilayer coatings, including nanostructured - currently they are made on an industrial scale (their examples are given in table I), but they are still subjects of research and development.

In the opinion of Gey from Kennametal [9], development of coatings deposited by the PVD method will mainly consist in further improvement of coatings based on TiAlN and AlCrN nitrides, among others by: adding vanadium and tungsten to their compositions - to improve the lubricating properties of the coatings (due to the formation of Magnéli oxide phases), adaptation and joining them with oxynitride layers (e.g. 
AlCrON), to form coatings based on high entropy alloys (HEA - high entropy alloy coatings), design of coatings with a specific microstructure and specific phase composition, and the use of modern techniques of applying high power pulse magnetron sputtering (HiPIMS).

Based on the review of recent developments in the field of coatings applied by the PVD method, it can be stated that dynamic development of cutting tools also applies to PVD coating with the cathodic-arc method $[9,10]$. Examples of multilayer coatings deposited by PVD methods, developed recently in the world, are presented in table II [11-16].

The subjects of development in the world, as well as in Łukasiewicz Research Network - The Institute of Advanced Manufacturing Technology, are multilayer nanostructured, often superlattice (SL) coatings, usually composed of nitride layers, and sometimes of oxynitrides. These coatings on cutting tools are mainly made using the cathode arc method, sometimes using the HiPIMS method, which is mainly used for depositing the outer layers of coatings (due to the lower surface roughness).

TABLE I. Examples of multilayer coatings used in the industry for tool blades [1]

\begin{tabular}{|c|c|c|c|}
\hline $\begin{array}{l}\text { Coating type } \\
\text { (most common } \\
\text { deposition method) }\end{array}$ & AlCrN (PVD) & TiAIN (PVD) & TiAIN + WC/C (PVD) \\
\hline Coating structure & Multilayered & Nano-layered & Multilayered \\
\hline $\begin{array}{l}\text { Hardness HV0.05 } \\
\text { (dry friction } \\
\text { coefficient against } \\
\text { steel) }\end{array}$ & $3200(0.3)$ & $3300(0.3-0.35)$ & $3000(0.15-0.2)$ \\
\hline $\begin{array}{l}\text { Maximum working } \\
\text { temperature }\left[{ }^{\circ} \mathrm{C}\right]\end{array}$ & 1100 & 900 & 800 \\
\hline Advantages & $\begin{array}{l}\text { High oxidation resistance } \\
\text { and high hot hardness }\end{array}$ & $\begin{array}{l}\text { High hot hardness and high oxidation } \\
\text { resistance }\end{array}$ & $\begin{array}{l}\text { High hardness, high } \\
\text { resistance to high } \\
\text { temperatures and } \\
\text { favorable lubrication and } \\
\text { sliding properties }\end{array}$ \\
\hline $\begin{array}{l}\text { Sample application } \\
\text { of the coating for } \\
\text { cutting edges of } \\
\text { machining tools }\end{array}$ & $\begin{array}{l}\text { High-speed steel and } \\
\text { cemented carbide tools } \\
\text { for drilling or reaming } \\
\text { steel (including stainless), } \\
\text { cast iron, aluminum alloys, } \\
\text { titanium, bronze, brass } \\
\text { and copper }\end{array}$ & $\begin{array}{l}\text { High speed steel and cemented } \\
\text { carbide tools for turning, milling, } \\
\text { drilling and threading carbon and } \\
\text { alloy steels up to } 52 \text { HRC hardness, } \\
\text { stainless steels, cast iron, nickel } \\
\text { alloys, titanium and aluminum, brass, } \\
\text { bronze and copper. Tools for } \\
\text { machining gears made of steel up to } \\
52 \text { HRC (including stainless steel), } \\
\text { cast iron, brass and bronze }\end{array}$ & $\begin{array}{l}\text { Carbide tools for turning } \\
\text { aluminum and its alloys, } \\
\text { brass, copper and bronze. } \\
\text { High-speed steel tools for } \\
\text { milling and threading } \\
\text { aluminum, brass and } \\
\text { bronze alloys. This coating } \\
\text { can be used for machining } \\
\text { brass and bronze gears }\end{array}$ \\
\hline
\end{tabular}

TABLE II. Examples of developed new multilayer coatings deposited by PVD methods

\begin{tabular}{|c|c|c|c|}
\hline Coating & Coating type & Main advantages & $\begin{array}{l}\text { Ref.: year } \\
\text { [item] }\end{array}$ \\
\hline AlTiN/VZrN & Multilayer nanostructural & $\begin{array}{l}\text { Coatings with high hardness, heat resistance, adhesion and } \\
\text { wear resistance, deposited with the arc and hybrid method } \\
\text { (arc with HiPIMS) }\end{array}$ & 2018 [11] \\
\hline TiVN/TiSiN & Multilayer on the nano scale & $\begin{array}{c}\text { Arc coatings on cemented carbides; characterized by high } \\
\text { hardness (35-37 GPa) and wear resistance in the milling } \\
\text { process }\end{array}$ & 2018 [12] \\
\hline AlCrTiN/CrN & $\begin{array}{l}\text { Multilayer on the nano } \\
\text { scale, composite with } \\
\text { Ni clusters }\end{array}$ & $\begin{array}{l}\text { Coatings deposited by means of an arc method with a } \\
\text { structure that reduces internal stresses and increases } \\
\text { resistance to cracking }\end{array}$ & 2018 [13] \\
\hline CrAIN/VN & Multilayer nanostructural & $\begin{array}{c}\text { Coatings applied by magnetron PVD method; characterized } \\
\text { by hardness 20-32 GPa, high wear resistance, low friction } \\
\text { coefficient and self-lubricating properties }\end{array}$ & 2017 [14] \\
\hline $\begin{array}{l}\mathrm{CrN} / \mathrm{Cr} \text { and } \\
\mathrm{TiN} / \mathrm{SiO}_{x}\end{array}$ & $\begin{array}{l}\text { Multilayer at the micro and } \\
\text { nano scale }\end{array}$ & $\begin{array}{l}\text { Coatings deposited by the magnetron method, in which } \\
\mathrm{SiO}_{x} \text { layers are } 35 \mathrm{~nm} \text { thick and TiN layers } 115-350 \mathrm{~nm} \text {; } \\
\text { increased crack resistance (ductility) from } 3.6 \text { to } 5 \mathrm{MPa} \cdot \mathrm{m}^{1 / 2}\end{array}$ & 2016 [15] \\
\hline AIN/CrN & Multilayer super-structural & Coatings with high rigidity (Young's modulus over $400 \mathrm{GPa}$ ) & 2015 [16] \\
\hline
\end{tabular}




\section{Selected examples of modern multilayer coatings developed at the Institute of Advanced Manufacturing Technology}

In the Institute of Advanced Manufacturing Technology, the NNW-6.6 unit was used to deposit the layers using the PVD arc method. During the coating processes, tools and samples rotated in the instrumentation placed on a rotary table in planetary seats, thus their rotation was much faster than the set rotational speed of the table. Due to the use of such a kinematic system and appropriate technological equipment, cyclical shading of the being-coated surfaces relative to the cathodes took place in short intervals of time. This produced super-thin layers on the coated surfaces (with a thickness of several nanometers).

Examples of modern nanostructured coatings, developed and manufactured at the Institute of Advanced Manufacturing Technology, are multilayer coatings based on alternating thin and super-thin TiN and ZrN nitrides.

The multilayer TiN/6×(ZrN/TiN)/Ti-Zr-N coating (fig. 2) had the following structure (order of layers from the substrate):

- Ti nanolayer with a thickness of up to approximately $50 \mathrm{~nm}$, improving adhesion of the coating to the substrate,

- TiN microlayer with a thickness of up to $1 \mu \mathrm{m}$, constituting an intermediate layer between Ti and the system of layers deposited alternately $\mathrm{TiN}$ and $\mathrm{ZrN}$, characterized by good adhesion to the metallic substrate,

- six thin alternating layers of $\operatorname{ZrN}$ (each with a thickness of approximately 250-300 nm) and TiN (each with a thickness of approximately 200-250 nm), improving the coating's resistance to cracking,

- Ti-Zr-N multilayer with a total thickness of about $2 \mu \mathrm{m}$, consisting of many super-thin, alternating layers of TiN and ZrN (each with a thickness of 6-7 nm; the thickness of was determined on the basis of kinematics and conditions of the PVD process - it is so small that the individual layers are not visible on the fractures' images obtained using a scanning electron microscope), which is a very hard material and resistant to wear.

The order of layers (from the substrate) in the Ti-Zr-N/10×(TiN/ZrN) coating was as follows (fig. 3):

- Ti nanolayer with a thickness of up to approximately $50 \mathrm{~nm}$, improving adhesion of the coating to the substrate,

- Ti-Zr-N multilayer with a total thickness of about $2 \mu \mathrm{m}$, consisting of many super-thin alternating layers of TiN and ZrN (each with a thickness of 6-7 nm, determined on the basis of kinematics and conditions of the PVD process, so small that the individual layers are not visible on the fractures' images obtained using a scanning electron microscope), which is a very hard material and resistant to wear,

- 10 thin alternating layers of TiN and ZrN (each with a thickness of 80-120 nm), improving the coating's resistance to cracking.

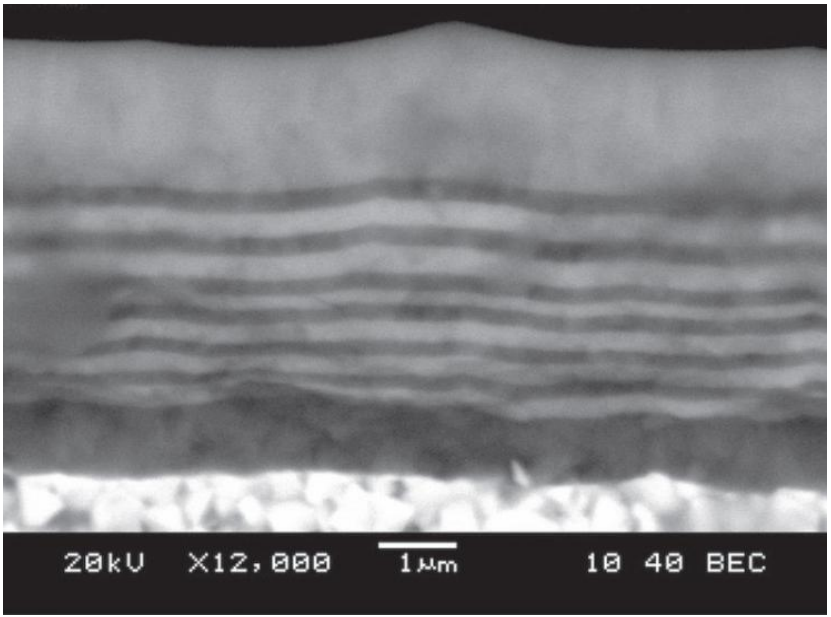

Fig. 2. Image of the fracture of the

TiN/6×(ZrN/TiN)/Ti-Zr-N coating obtained with a scanning electron microscope at $12,000 \times$ magnification, BEC

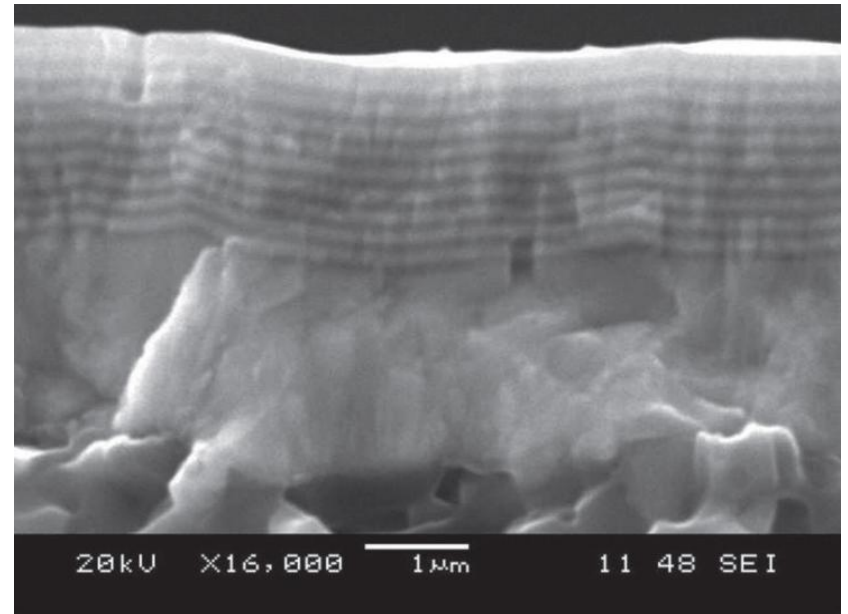

Fig. 3. Image of the fracture of

the Ti-Zr-N/10×(TiN/ZrN) coating obtained with a scanning electron microscope at $16,000 \times$ magnification, SEI

The deposited coatings were tested by observing transverse fractures as well as transverse and low-angle $\left(5-6^{\circ}\right)$ tapered metallographic sections by a scanning electron microscope Jeol SM 6460LV. Using this microscope, the thickness of multilayer coatings and their micro- and nanolayers included in the fractures 
were determined. The hardness of coatings and substrates was determined on low-angle tapered metallographic sections by the Vickers method (at a load of $0.2452 \mathrm{~N}$ ) using a digital microhardness tester type FM-7 from Future-Tech Corp. The phase composition analysis, presented in fig. 4 for the TiN/6×(ZrN/TiN)/Ti-Zr-N coating, was performed using a PANalytical Em-pyrean X-ray diffractometer (Cu $K \alpha_{1}$ lamp $=1.5417 \AA, U=40 \mathrm{kV}, I=30 \mathrm{~mA}$ ) and the PANalytical High Score Plus program, integrated with the ICDD PDF4+ 2018 crystallographic database. Surface roughness measurements on TiN/6×(ZrN/TiN)/Ti-Zr-N and Ti-Zr-N/10×(TiN/ZrN) coatings and surfaces machined with cutters coated with TiN/6×(ZrN/TiN)/Ti-Zr$\mathrm{N}$ and commercial coating were made with the Hommel Tester T1000 profilometer. Cutting ability of milling cutter blades with TiN/6×(ZrN/TiN)/Ti-Zr-N coating and commercial coating was determined in machining the Toolox 44 steel applied for dies, performed on a CNC milling center of DMC 75 V Linear type manufactured by DMG MORI firm.

TiN/6×(ZrN/TiN)/Ti-Zr-N coating was deposited, on, among others, a cemented carbide substrate - on 4flute end mills with a diameter of $\varnothing 8 \mathrm{~mm}$. The total thickness of the coating, determined on the basis of observations on the fracture (using a scanning electron microscope) of the structure of the surface layer with the coating, was about $6 \mu \mathrm{m}$. The coating thickness for Ti-Zr-N/10×(ZrN/TiN) was about $4 \mu \mathrm{m}$.

$\mathrm{X}$-ray diffraction analysis showed the presence of two nitride phases TiN and $\mathrm{ZrN}$ in the TiN/6×(ZrN/TiN)/Ti-Zr-N coating. On the X-ray diffraction pattern (fig. 4), one can also observe the intensity peaks from the substrate (WC carbide).

The coating structure consisted of thin and super-thin alternating layers of TiN and ZrN nitrides. Nitrides forming a multilayer, composed of very numerous and very thin alternating layers of TiN and ZrN (thickness of several nanometers), crystallize in a cubic regular system (type B1) and have similar lattice parameters $0.432 \mathrm{~nm}(4.32 \AA)$ and $0.456 \mathrm{~nm}(4.56 \AA)$, respectively. Structures of this type with similar lattice parameters, alternating in very thin layers (of the order of nanometers), can create superlattice that cause a clear increase in hardness compared to the hardness of nitrides of the component layers.

Research carried out in the Institute of Advanced Manufacturing Technology on the deposition of this type of Ti-Zr-N multilayer structures on cemented carbide and high speed steel substrates confirmed the very high hardness of these coatings, 3500-3800 HV0.025 (measurements on low-angle tapered sections). Very high hardness of coatings containing alternating super-thin $\mathrm{ZrN}$ and TiN nitride layers and observations of their structure on the low-angle tapered sections under high magnification indicate that the obtained coatings are superlattices. The unequivocal determination of whether a superlattice exists in a given multilayer of the coating requires additional testing using a transmission electron microscope.

The average value of the parameter $R a$ of surface roughness of the TiN/6×(ZrN/TiN)/Ti-Zr-N multilayer coating was (based on four measurements) $0.27 \mu \mathrm{m}$ (standard deviation $0.08 \mu \mathrm{m}$ ), and the multilayer coating Ti-Zr-N/10×(TiN/ZrN) (for one hundred measurements) - $0.37 \mu \mathrm{m}$ (standard deviation $0.05 \mu \mathrm{m}$ ). The higher value of the $R a$ parameter for one of the coatings may be due to the higher roughness of the substrate and the larger number of micro-droplets occurring in the arc method when applying - as the outer layer - ZrN nitride.

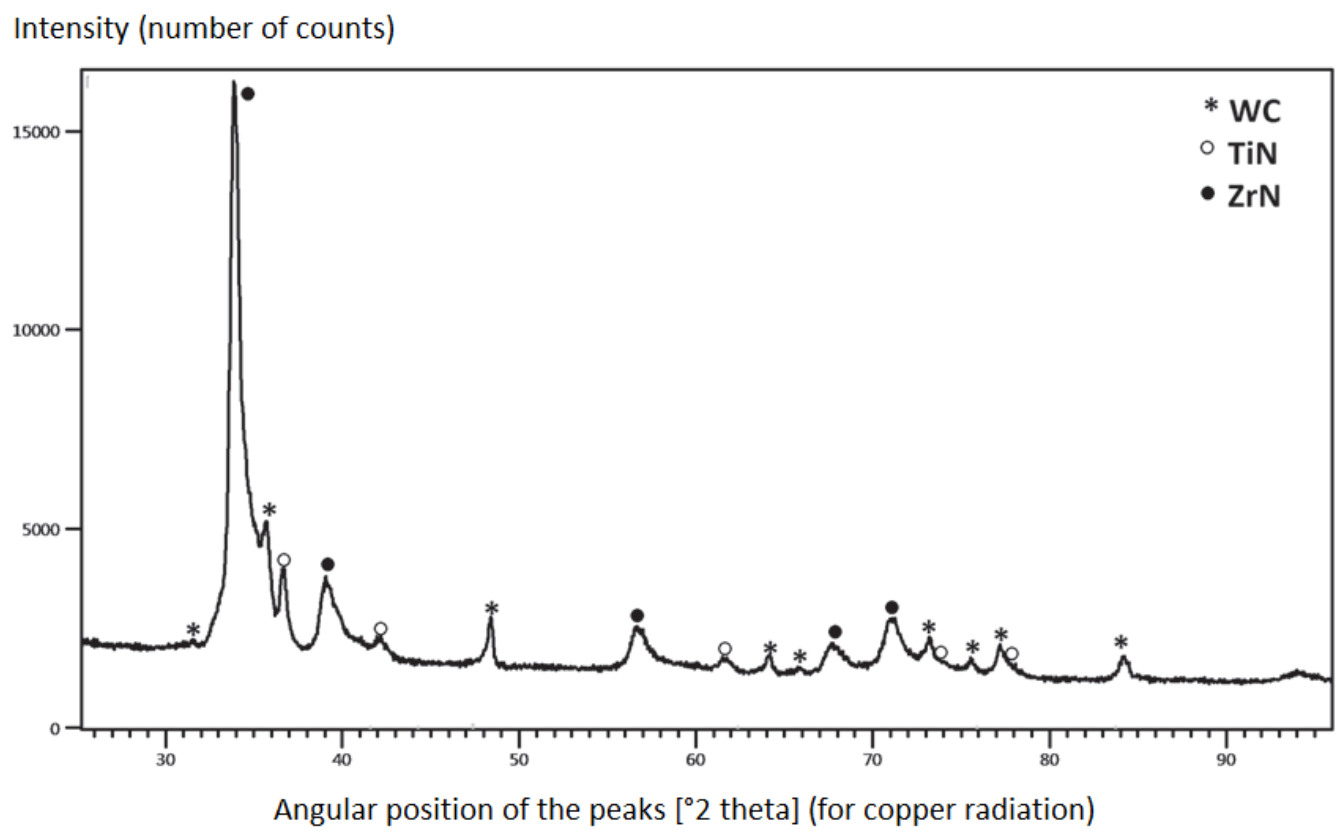

Fig. 4. X-ray diffraction pattern of the TiN/ $6 \times(\mathrm{ZrN} / \mathrm{TiN}) / \mathrm{Ti}-\mathrm{Zr}-\mathrm{N}$ coating phase composition on a carbide substrate 
TABLE III. $V B_{\max }$ wear values after different milling times of Toolox 44 steel with end mills (tested and compared)

\begin{tabular}{|c|c|c|c|c|}
\hline \multirow[t]{2}{*}{ Coated cutter } & \multirow[t]{2}{*}{ Parameter } & \multicolumn{3}{|c|}{$\begin{array}{l}V B_{\max }[\mathrm{mm}] \text { wear values } \\
\text { after milling time } t \text { [min] }\end{array}$} \\
\hline & & $t=44$ & $t=66$ & $t=88$ \\
\hline \multirow{2}{*}{ Ti1000 (commercial) } & Mean & 0.21 & 0.28 & 0.32 \\
\hline & Standard deviation & 0.02 & 0.01 & 0.02 \\
\hline \multirow{2}{*}{$\begin{array}{c}\text { TiN/6×(ZrN/TiN)/Ti-Zr-N } \\
\text { (Łukasiewicz Research Network - The Institute of Advanced } \\
\text { Manufacturing Technology) }\end{array}$} & Mean & 0.17 & 0.23 & 0.29 \\
\hline & Standard deviation & 0.02 & 0.02 & 0.02 \\
\hline
\end{tabular}

TABLE IV. Values of roughness parameter $R a$ of the surface machined after different milling times of Toolox 44 steel with end mills (tested and compared)

\begin{tabular}{|c|c|c|c|c|c|}
\hline \multirow[t]{2}{*}{ Coated cutter } & \multirow[t]{2}{*}{ Parameter } & \multicolumn{4}{|c|}{$\begin{array}{l}\text { Roughness parameter } R a[\mu \mathrm{m}] \text { of the } \\
\text { machined surface after milling time } t \\
\text { [min] }\end{array}$} \\
\hline & & $t=22$ & $t=44$ & $t=66$ & $t=88$ \\
\hline \multirow{2}{*}{ Ti1000 (commercial) } & Mean & 0.37 & 0.32 & 0.17 & 0.17 \\
\hline & Standard deviation & 0.08 & 0.18 & 0.05 & 0.04 \\
\hline \multirow{2}{*}{$\begin{array}{c}\text { TiN/ } 6 \times(\mathrm{ZrN} / \mathrm{TiN}) / \mathrm{Ti}-\mathrm{Zr}-\mathrm{N} \\
\text { (Łukasiewicz Research Network }- \text { The Institute of } \\
\text { Advanced Manufacturing Technology) }\end{array}$} & Mean & 0.25 & 0.18 & 0.10 & 0.19 \\
\hline & Standard deviation & 0.19 & 0.08 & 0.04 & 0.03 \\
\hline
\end{tabular}

Cutting ability of tools' wedges with TiN/6×(ZrN/TiN)/Ti-Zr-N coating, deposited on 4-flute end mills with a diameter of $\varnothing 8 \mathrm{~mm}$ made of cemented carbide (in this case, milling cutters manufactured by WNT type 52181 080 ), was tested in cutting tests of a flat surface with dimensions of $53 \times 250 \mathrm{~mm}$. To get closer to real machining conditions, a rectangular pocket with a wall thickness of $3 \mathrm{~mm}$ and a corner radius $R$ of $16 \mathrm{~mm}$ was made on a flat surface. The worked material was Toolox 44 steel with a hardness of 44-45 HRC. Concurrent (climb) milling with cutting fluid in the form of an 8\% oil emulsion (Hysol R oil), cutting speed $v_{\mathrm{c}}=100$ $\mathrm{m} / \mathrm{min}$, feed per tooth $f_{\mathrm{z}}=0.015 \mathrm{~mm}$, depth of cut $a_{\mathrm{p}}=0.5 \mathrm{~mm}$, milling cutter entry along helical line with a feed-in of $25 \%$ of $f_{\mathrm{z}}$ and track overlap factor of 0.5 (milling width $a_{\mathrm{e}}=2 \mathrm{~mm}$ ), were applied. As the criterion of wear of the milling cutter, the wear value $V B_{\max }=0.30 \mathrm{~mm}$ exceeding was assumed.

The machining was carried out on a DMG MORI CNC milling center type DMC 75 V Linear. The cutter with the coating deposited in the Institute of Advanced Manufacturing Technology was compared with a WNT type 52183080 end mill with similar geometry and a commercial Ti1000 coating with a hardness of 3500 HV0.05. Table III presents the mean values of $V B_{\max }$ flank wear land length on the flank face of end mills after various cutting times (number $i=4$ ), resulting from multiples of pocket milling time. The roughness parameter $R a$ of the worked surface was also measured - the results are given in table IV.

Based on the results of cutting abilities of coated end mills tests, it was found that after cutting time $t 88 \mathrm{~min}$, the mean wear value for commercial coated milling cutters, $V B_{\max }$ was $0.32 \mathrm{~mm}$, and thus exceeded the adopted criterion of wear $V B_{\max }$ of $0.3 \mathrm{~mm}$, while for milling cutters with TiN/6×(ZrN/TiN)/Ti-Zr-N coating - $V B_{\max }$ was $0.29 \mathrm{~mm}$. These differences are not large, but favor cutters with a coating deposited in the Institute of Advanced Manufacturing Technology. After verifying the hypothesis about the equality of mean values using the Student's t-test, the test value of 2.121 was obtained, i.e. less than the critical value of 2.447 at the significance level of 0.05 and greater than the critical value of 1.943 at the significance level of 0.10 .

In the milling time range of up to 66 min, lower surface roughness, determined using the $R a$ parameter, was obtained after machining using milling cutters with TiN/6×(ZrN/TiN)/Ti-Zr-N coatings when compared to commercial milling cutters (end mills). When the milling time exceeded $88 \mathrm{~min}$, the $R a$ parameter values became very near.

\section{Summary}

The multilayers used in the structure of coatings, composed of many super-thin, alternating layers of TiN and $\mathrm{ZrN}$ (with a thickness of several nanometers each), are very hard and resistant to wear. Thickness of the super-thin layers, determined on the basis of the kinematics and conditions of the PVD process, is so small that these layers were not visible on the images of fractures obtained using a scanning electron microscope. High hardness of the coatings (on the order of 3500-3800 HV0.025) and observations of the microstructure of the coatings at high magnification on low-angle tapered metallographic sections indicate that they are 
superlattice coatings. Cutting process investigations have confirmed that multilayer nanostructured coatings are suitable for manufacturing applications.

\section{REFERENCES}

[1] Materiały informacyjne firm: Oerlikon-Balzers, Ionbond, Platit, Ceme-Con, Hauzer, SHM, Gühring, VUHZ; 20142019.

[2] Burakowski T., Wierzchoń T. „Inżynieria powierzchni metali - podstawy, urzqdzenia, technologie”. Warszawa: WNT, 1995.

[3] Anders A. "A review comparing cathodic arcs and high power impulse magnetron sputtering (HiPIMS)". Surface \& Coatings Technology. 257 (2014): 308-325, https://doi.org/10.1016/j.surfcoat.2014.08.043.

[4] Czechowski K., Wronska I., Toboła D. „Powłoki na ostrza narzędzi z węglików spiekanych i stali szybkotnących. Obróbka Skrawaniem 8. Synergia Nauki z Przemysłem". Red.: M. Pajor. VIII Szkoła Obróbki Skrawaniem. Międzyzdroje-Szczecin 2014, s. 109-118.

[5] Czechowski K. „Wpływ nanostrukturalnych powłok wielowarstwowych na właściwości użytkowe narzędzi” ("Effect of nanostructured multilayer coatings on functional properties of tools"). Mechanik. 1 (2017): 28-33, DOI: https://doi.org/10.17814/mechanik.2017.1.27 (PL, ENG).

[6] Panckow A.N., Steffenhagen J., Wegener B., Dübner L., Lierath F. "Application of a novel vacuum-arc ion-plating technology for the design of advanced wear resistant coatings". Surface \& Coatings Technology. 138, 1 (2001): 71-76, https://doi.org/10.1016/S0257-8972(00)01150-6.

[7] BALZERS. „Przyszłość to NANO”. Materiały informacyjne. 2005.

[8] Bobzin K. "High-performance coatings for cutting tools". CIRP Journal of Manufacturing Science and Technology. 18 (2017): 1-9, https://doi.org/10.1016/j.cirpj.2016.11.004.

[9] Williams B., Lausecker U., Gey Ch. "19 ${ }^{\text {th }}$ Plansee Seminar: Production trends in refractory metals and hard materials". Powder Metallurgy Review. Autumn/Fall (2017): 79-86.

[10] Cselle T., Lümkemann A., Jilek M. sen., Jilek M. jun. "My tool, my coating”. Werkstatt+Betrib. 11 (2016): 1-5.

[11] Vetter J., Kubota K., Isaka M., Mueller J., Krienke T., Rudigier H. "Characterization of advanced coating architectures deposited by an arc-HiPIMS hybrid process". Surface \& Coatings Technology. 350 (2018): 154160, https://doi.org/10.1016/i.surfcoat.2018.05.075.

[12] Chang Y.-Y., Chang H., Jhao L.-J., Chuang Ch.-Ch. "Tribological and mechanical properties of multilayered TiVN/TiSiN coatings synthesized by cathodic arc evaporation". Surface \& Coatings Technology. 350 (2018): 1071-1079, https://doi.org/10.1016/i.surfcoat.2018.02.040.

[13] Best J.P., Polyakov M., Shinde D., Colliander M.H., Wehrs J., Michler J., Morstein M. "Ni nanocluster composites for enhanced impact resistance of multilayered arc-PVD ceramic coatings". Surface \& Coatings Technology. 354 (2018): 360-368, https://doi.org/10.1016/i.surfcoat.2018.07.102.

[14] Wang Y., Lee J.-W., Duh J.-G. "Mechanical strengthening in self-lubricating CrAlN/VN multilayer coatings for improved high-temperature tribological characteristics". Surface \& Coatings Technology. 303 (2016): 12-17, https://doi.org/10.1016/j.surfcoat.2016.02.003.

[15] Daniel R., Meindlhumer M., Zalesak J., Sartory B., Zeilinger A., Mitterer Ch., Keckes J. "Fracture toughness enhancement of brittle nanostructured materials by spatial heterogeneity: A micromechanical proof for $\mathrm{CrN} / \mathrm{Cr}$ and $\mathrm{TiN}_{\mathrm{SiO}}$ multilayers". Materials and Design. 104 (2016): 227-234, https://doi.org/10.1016/i.matdes.2016.05.029.

[16] Friák M., Tytko D., Holec D., Choi P.P., Eisenlohr P., Raabe D., Neugebauer J. "Synergy of atom-probe structural data and quantum-mechanical calculations in a theory-guided design of extreme-stiffness superlattices containing metastable phases". New J. Phys. 17 (2015): 093004, https://doi.org/10.1088/1367$\underline{2630 / 17 / 9 / 093004 .}$. 